\title{
Corporate Governance and Returns on Investments of Pakistani Listed Companies
}

\author{
Nouman Afgan ${ }^{1, *}$, Klaus Gugler ${ }^{2}$, Robert M. Kunst ${ }^{3,4}$ \\ ${ }^{1}$ Department of Management Sciences, Preston University, Pakistan \\ ${ }^{2}$ Department of Economics, Vienna University of Economics and Business, Austria \\ ${ }^{3}$ Department of Economics, University of Vienna, Oskar Morgenstern Platz 1, A-1090, Vienna, Austria \\ ${ }^{4}$ Institute for Advanced Studies Vienna, Josefstadter Strasse 39, A-1080 Vienna, Austria (ORCID: 0000-0001-6831-2471)
}

Copyright $\odot 2017$ by authors, all rights reserved. Authors agree that this article remains permanently open access under the terms of the Creative Commons Attribution License 4.0 International License.

\begin{abstract}
This paper analyzes the effects of corporate governance institutions on investment returns of Pakistani listed companies. A marginal $q$ is used to estimate returns on investments from cash flows, debt, and equity. Return on total investment is $31 \%$ lower than the cost of capital, which suggests that largest shareholders or managers invest beyond the optimal investment level that maximizes the wealth of shareholders. Return on reinvested cash flow is $30 \%$ lower than the cost of capital. There is evidence of our hypothesis that largest shareholders or managers exercise discretion while reinvesting cash flows. Return on investment financed from debt is lower than the cost of capital as financial institutions are faced with asymmetric information while analyzing creditworthiness of investments. The analysis provides evidence of market discipline on investments financed from debt by companies whose ultimate shareholders are foreign entities. Corporate governance institutions are unable to control managers of foreign-owned companies from issuing equity to finance investments with returns lower than the costs of capital. Financial market development is retarded because outside shareholders are reluctant to invest in equities and financial institutions are wary of financing borrowers. The weak corporate governance system is unable to properly protect financial institutions from loan delinquencies.
\end{abstract}

JEL Classification: L2, G3

Keywords Corporate Governance, Ultimate Ownership, Asymmetric Information, Market Discipline, Investment Performance

\section{Introduction}

Analysis of the effects of corporate governance institutions on returns on investments of publicly-listed companies is important for industrialized countries that have strong corporate governance systems. It is all the more important for the developing economy of Pakistan that has a weak corporate governance system. In a weak corporate governance system, creditors are wary of loan delinquencies and minority shareholders are reluctant to invest in the shares of listed companies as they face expropriation by dominant largest shareholders or managers. External capital markets develop only if capital market institutions properly protect creditors from loan delinquencies and minority shareholders from expropriation by largest shareholders.

This paper analyzes the ownership structures of 125 Pakistani listed companies over the period 1997 to 2007. It is the first study on a South Asian country that uses a marginal $q$ to measure performance that has been derived from the micro theory of the firm. Marginal $q$ is defined as the ratio of return on investment to the cost of capital. The concept of marginal $q$ appears to be more adequate than alternative approaches that use average performance measures such as return on assets, or market to book value that confounds infra-marginal and marginal returns and is not ideal for the analysis of agency problems. The use of marginal $q$ for measuring performance not only obviates the need to calculate costs of capital but also allows for different degrees of risks across companies.

In this paper, we present evidence that marginal $q$ on investment $\left(q_{m I}\right)$ is 0.69 , which suggests that largest shareholders or managers invest beyond the optimal level of investment that maximizes the wealth of the shareholders. Thus, they pursue their own objectives. Marginal $q$ on reinvested cash flows and investments financed from debt and equity offerings are estimated. We present evidence that marginal $q$ on reinvested cash flow is less than 1 . The exercise of discretion by the largest shareholders or managers while reinvesting cash flows, among other factors, leads to returns on reinvested cash flows lower than the costs of capital.

Marginal $q$ on investment financed from debt is significantly less than 1 , which implies presence of 
asymmetric information in the process of evaluating the credit worthiness of investments financed by financial institutions. Asymmetric information about the prospects of the investment projects being financed enables borrowers to obtain loans for investments that yield returns lower than the costs of capital. The weak corporate governance regime in Pakistan is unable to properly protect financial institutions from loan delinquencies as the foreclosure laws are weak. Due to the high transaction costs of issuing equity and weak foreclosure laws, largest shareholders or managers rely primarily on reinvested cash flows and loans from financial institutions and debt issues to finance investments.

Section 2 gives an overview of the literature on returns on investment from cash flows, debt and equity. Section 3 presents our hypotheses. Section 4 focuses on the problem of determining ultimate ownership. Section 5 consists of the methodology used for estimating the returns on investments relative to the cost of capital. In section 6 , we describe the sources of information, and report the statistics and correlation coefficients of variables used in the regression analysis. Section 7 comprises of analyses of the effects of weak corporate governance institutions and ownership structures on returns on investments from cash flows, debt and equity. Conclusions are drawn in the final section.

\section{Literature Review}

Tobin [1] illustrated the capital account approach (schematic) for a closed economy. In his general accounting framework, a row may be labeled as demand deposits or producers' durable equipment, whereas columns represent sectors of the economy that are constrained by their own wealth. Examples of sectors are commercial banks, central bank, non-bank financial institutions, and the general public. In this approach, financial policies and events mainly affect aggregate demand by changing the valuations of physical assets relative to their replacement costs. Monetary policies can accomplish such changes, but other exogenous events can too.

Hayashi [2] analyzed for US corporations the idea that investment is a function of marginal $q$ (the ratio of market value of an additional unit of capital to its replacement cost). He tests the conjecture put forward by Tobin and derives the optimal rate of investment as a function of marginal $q$ adjusted for tax purposes. The ratio of corporate investment to the total capital stock at replacement cost is regressed on marginal $q$ over the period 1953 to 1976 , which gives a positive coefficient on marginal $q$. The analysis shows that marginal $q$ and average $q$ (the ratio of market value of existing capital to its replacement cost) are the same in the special case if the company is a price taker and the production and installation functions are homogenous.

Hoshi et al. [3] present evidence from Japanese companies, which is consistent with the view that information and incentive problems in the capital market have important effects on corporate investment. They hypothesize that group firms are not subject to asymmetric information problems when financing their investments because other group members have access to information. Tobin's $q$ is used as a proxy for investment prospects. The sample is divided into 176 independent and 121 group companies. The dependent variable is depreciable assets divided by the capital stock. The measures of liquidity used are cash flow and short-term securities. Cash flow has a positive significant coefficient only in the investment equation for independent companies. Contrary to the over-investment hypothesis that predicts a negative coefficient for both interaction terms, the difference between liquidity coefficients of group companies and non-group companies is larger for high Tobin's $q$ firms.

Fazzari et al. [4] tested the asymmetric information hypothesis by basing their test solely on the financial constraint part of the hypothesis. They divided the sample of 422 US companies into low, medium, and high retention ratio sub-samples, and used them to estimate cash flowinvestment equations, which also included Tobin's $q$ to analyze differences in investment opportunities.

According to the investment literature, there is a hierarchy of finance in the financing patterns of firms. Firstly, firms use cash flows to finance investments. Secondly, they issue debt and finally they approach the equity market. Myers [5] reports that US companies rely heavily on internal funds and debt to finance investments. Myers [6] reviews the theories of capital structure; capital structure irrelevance, trade-off theory, agency theory, and pecking order theory.

Singh [7] elaborates that there is a pecking order in the financing of corporate investments in developed countries such as USA and UK. Large corporations firstly use retained earnings for investments, then obtain loans or issue long-term bonds for financing investments and finally approach the equity market for issuing capital. He analyzes the financing patterns of 100 largest listed companies from India, South Korea, Jordan, Pakistan, Thailand, Malaysia, Turkey, Brazil, Mexico, and Zimbabwe over the period 1980 to 1990 .

The study provides evidence that large corporations in developing countries prefer equity offerings over debt for financing investments from the external capital market. Internal financing is measured by the proportion of growth of net assets financed by retentions, and external financing by growth of net assets financed by debt and equity.

Although there is a high inter-country dispersion in the percentages of internal finance, long-term debt and equity used by the median company for financing growth of net assets, companies do rely on external sources for financing growth. Specifically, the proportion of growth of net assets financed from debt is 38.9 percent, 30.4 percent, and 23.9 percent for India, Korea, and Pakistan respectively. However, this proportion is lower than 20 percent for all other countries in the sample. Turkey, Korea and Malaysia heavily use equity for financing corporate growth (see Singh [7] pp 129-131 for a country-wise comparison of financing of corporate growth from firm's internal sources, debt, and equity offerings; see also Singh [8]). 
Mueller and Yurtoglu [9] estimate marginal $q$ 's on investments from cash flow, debt and equity offerings for a sample of companies from 38 countries. They categorize countries by origins of economic and legal systems and report that marginal $q$ on reinvested cash flows is lower than 1 for some countries from all types of legal origin. In these cases, investments out of internal cash flows yield the worst performance. For other countries, again from all types of legal origin, marginal $q$ 's on debt and equity are equal to or greater than 1. In these cases, this holds for investments out of debt as well as for investments out of cash flows. On the whole, countries with English-origin legal systems tend to perform better than others. Thus, external capital markets are effective in forcing managers to earn marginal $q$ 's on debt and equity equal to or greater than 1 .

Gugler, Mueller, and Yurtoglu [10] analyze the effect of corporate governance institutions and ownership structures on investment performance by using a sample of more than 19000 companies from 61 countries. They use marginal $q$ to measure performance and show that origin of legal system is the most important determinant of performance. Companies in countries with a legal system of English origin earn at least equal to their costs of capital and companies in countries with civil law systems earn returns on investment below their costs of capital. Differences in performance that are related to a country's legal systems dominate differences that are related to ownership structures.

In a pioneering study, Samad [11] analyzes corporate governance and performance of Malaysian listed companies for the period 1989 to 1998 . She measures performance by return on equity and return on assets. The regression analysis insinuates that, as companies grow larger, they become more profitable and rely less on debt financing. It is concluded that being part of a business conglomerate is negatively related to performance.

Mueller [12] emphasizes the need for strong corporate governance institutions to facilitate the creation of thick equity markets in developing countries. Managers of companies in South East Asian developing countries have more discretion to make poor investments from debt and equity issues because corporate governance institutions are weaker in developing than in developed countries. Sometimes, growth maximizing managers of companies in Asian developing countries make excessive use of equity to finance questionable investments. Thus, investors in South East Asian countries are willing to invest in the shares of listed companies without sufficient regulatory protection.

Patti and Hardy [13] study the effect of banking sector reforms during the 1990s on the average cost and profit of Pakistani listed banks over the period 1981 to 2002. The reforms deregulated interest rates, eliminated directed credits, liberalized foreign currency deposits, and introduced market-based government securities. Competition in the banking sector became intense and new regulations on impaired loans and provisions for their recovery changed the productivity of banks. Their analysis shows that state-owned banks are the least efficient among state-owned banks, privatized banks, and private banks. However, privatization of state-owned banks and reforms has generally improved their performance during 1993 to 1997.

There are no studies for South Asian countries, which analyze return on investments from cash flows and external financing. This paper fills this gap for Pakistan.

\section{Hypotheses}

In a weak corporate governance system, interests of dominant largest shareholders or managers are not aligned with outside shareholders. Pakistan has a weak corporate governance system. This suggests the following hypothesis:

\section{Hypothesis 1}

The return on investment relative to the cost of capital is less than 1 for Pakistan.

Notwithstanding this hypothesis, there are companies in Pakistan, which have lucrative investment opportunities. Outside shareholders do not disagree with the largest shareholder or manager on investment policies as they want the company to capitalize on investment opportunities.

\section{Hypothesis 2}

Largest shareholders or managers exercise discretion while reinvesting cash flows for investments that have returns lower than the costs of capital.

It is hypothesized that return on reinvested cash flow is lower than the cost of capital.

\section{Ownership Structures}

Ownership structures of Pakistani listed companies are highly concentrated. Analysis of ownership structures shows that families, directly or indirectly, own $55.20 \%$ of the companies. The concept of a pyramidal structure is explained by illustrating the ownership structure of Maple Leaf Cement ${ }^{5}$ in figure 1.

Maple Leaf Cement uses the one share-one vote principle for issuance of shares (see Adams and Ferreira [14]). The largest direct shareholder of the company is Kohinoor Textile Mills that exports fabrics. It has shareholdings of $50.13 \%$. Kohinoor Textile Mills' largest direct shareholder is Zimpex Private Limited that has shareholdings of $15.47 \%$. Zimpex Private Limited is fully-owned at the top of the pyramidal structure by its directors, Tariq Sayeed Saigol and Taufique Sayeed Saigol, whose voting rights $(V R)$ are calculated as follows:

Voting Rights $(\mathrm{VR})=0.01+50.13+0.04=50.18 \%$ or 0.502

Cash flow rights are calculated by multiplying and

\footnotetext{
${ }^{5}$ Maple Leaf Cement was the highest traded equity at the Karachi Stock Exchange on August 21, 2014 and April 08, 2015. It was the second highest traded equity on January 21, 2016.
} 
summing over all relevant control chains as follows:

Cash flow rights $(C F R)=0.01+0.5013 \times(0.1547+0.1491)+$ 0.04

$\mathrm{CFR}=15.28 \%$ or 0.15

Cash flow leverage $(V R / C F R)$ is 3.28. Pyramidal structures lead to a divergence of the interests of the largest ultimate shareholder and those of outside shareholders because voting rights of the ultimate shareholder exceed cash flow rights (see e.g. Almeida and Wolfenzon [15]).
Table 1 reports the ownership concentration by the identity of direct and ultimate shareholders. The variable Ownership expresses the mean (median) of ownership whenever these identities are largest direct shareholders. Voting rights are applicable to the largest ultimate shareholders that are families, the state, and foreign entities. Diverging voting rights and cash flow rights are not analyzed because voting rights exceed cash flow rights in $11.2 \%$ of the companies.

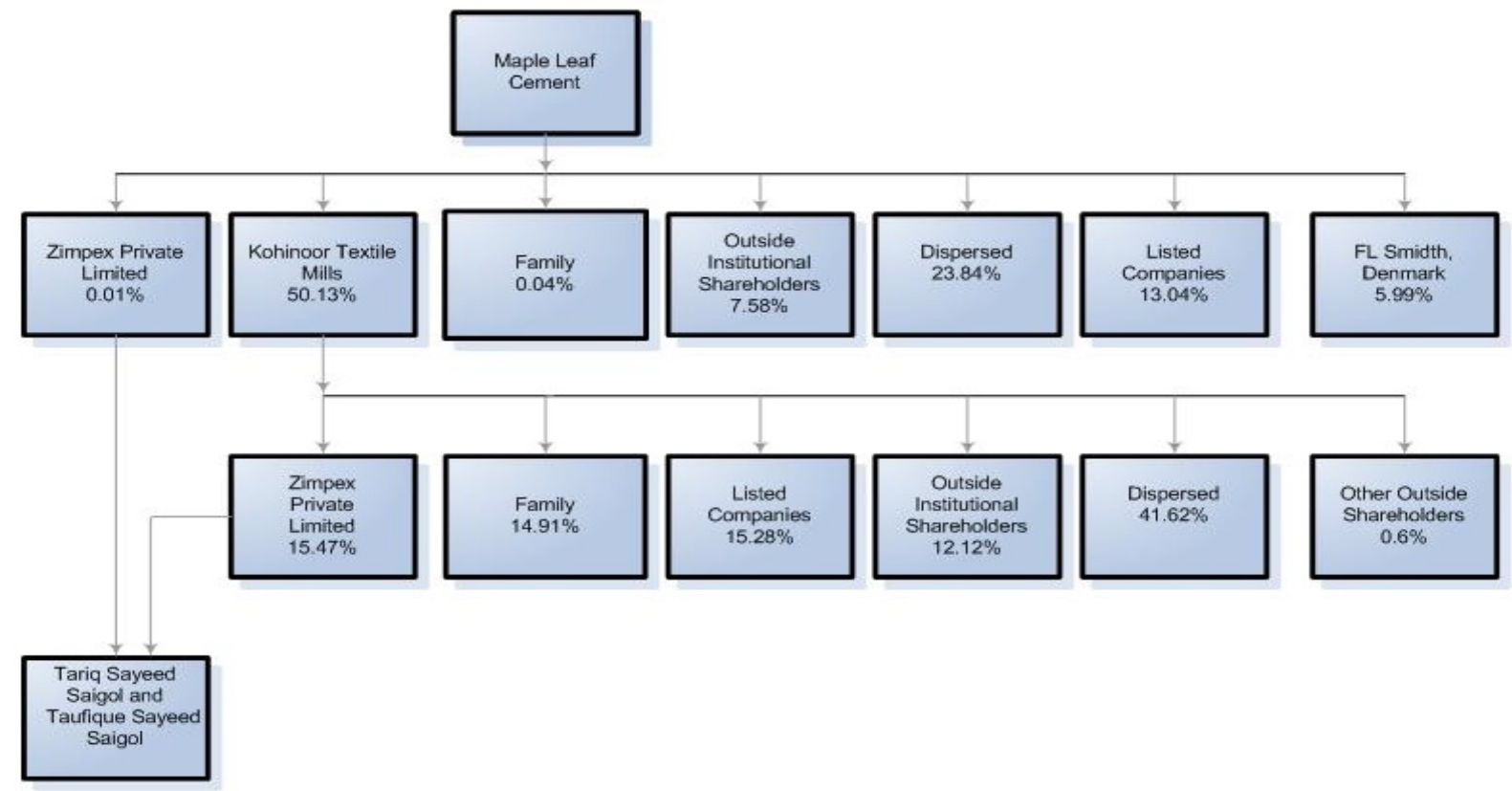

Figure 1. Ownership Structure of Maple Leaf Cement

Table 1. Ownership and control structures of Pakistani listed companies

\begin{tabular}{|c|c|c|c|c|c|c|c|}
\hline \multirow{4}{*}{$\begin{array}{l}\text { Ownership } \\
\text { Panels } \\
\text { Ownership } \\
\text { Identity }\end{array}$} & \multicolumn{3}{|c|}{ Direct Ownership Panel } & \multicolumn{4}{|c|}{ Ultimate Ownership Panel } \\
\hline & \multicolumn{3}{|c|}{ Largest Direct Shareholders } & \multicolumn{4}{|c|}{ Largest Ultimate Shareholders } \\
\hline & \multirow{2}{*}{$\begin{array}{l}\text { Companies } \\
\text { Percentage }\end{array}$} & \multicolumn{2}{|c|}{ Ownership } & \multicolumn{2}{|c|}{$\begin{array}{c}\text { Voting Rights } \\
(V R)\end{array}$} & \multicolumn{2}{|c|}{ Companies } \\
\hline & & Mean & Median & Mean & Median & Percentage & $\begin{array}{c}\text { Number } \\
(N)\end{array}$ \\
\hline $\begin{array}{c}\text { Private } \\
\text { Companies }\end{array}$ & 10.40 & 46.51 & 44.43 & & & & \\
\hline $\begin{array}{c}\text { Listed } \\
\text { Companies }\end{array}$ & 8.00 & 36.25 & 37.04 & & & & \\
\hline $\begin{array}{l}\text { Holding } \\
\text { Companies }\end{array}$ & 4.00 & 62.48 & 55.00 & & & & \\
\hline $\begin{array}{l}\text { Institutional } \\
\text { Shareholders }\end{array}$ & 1.60 & 30.56 & 30.56 & & & & \\
\hline Trusts & 4.80 & 40.28 & 40.00 & & & & \\
\hline Families & 30.40 & 48.03 & 43.46 & 52.02 & 46.58 & 55.20 & 69 \\
\hline State & 6.40 & 60.72 & 60.30 & 61.89 & 60.93 & 10.40 & 13 \\
\hline Foreign & 34.40 & 61.23 & 62.02 & 67.94 & 66.92 & 34.40 & 43 \\
\hline Total & 100.00 & 52.45 & 50.88 & 58.56 & 54.53 & 100.00 & 125 \\
\hline
\end{tabular}


Tracing the ultimate ownership of companies shows that families and the state control $55.2 \%$ and $10.4 \%$ of the companies respectively. Foreign entities control $34.40 \%$ of the companies. However, none of these entities have the state as the ultimate shareholder. Table 1 illustrates that ultimate ownership is a more meaningful concept than direct ownership. In Pakistan, the concentration of ultimate voting rights is very high, the average share of voting rights owned by the largest shareholders is almost $60 \%$.

\section{Model}

Investment performance is estimated by using a marginal $q$, i.e. the ratio of a company's return on investment to its cost of capital (see Mueller and Reardon [16]). Suppose $I_{t}$ is a company's investment in period $t$, then the present value of this investment, $P V_{t}$, in period $t$ is as follows:

$$
P V_{t}=\sum_{j=1}^{\infty} C F_{t+j} /\left(1+i_{t}\right)^{j}
$$

Here $P V_{t}$ is the present value of the investment $I_{t}$ in the period $t, C F_{t+j}$ is the cash flow generated from $I_{t}$ in period $(t+j)$, and $i_{t}$ is the cost of capital in period $t$. For example, a given investment of 100 might produce a future stream of cash flows with a present value $\left(P V_{t}\right)$ of 132.62 .

$P V_{t}$ from equation (1) and the investment $\left(I_{t}\right)$ that created it can be used to determine the ratio of a pseudo-permanent return $\left(r_{t}\right)$ to $i_{t}$, a ratio that will be referred to as $q_{m t}$ :

$$
P V_{t}=I_{t} r_{t} / i_{t}=q_{m I} I_{t}
$$

Here $r_{t}$ is the pseudo-permanent return on $I_{t}$ and $i_{t}$ is the cost of capital. If the company had invested the same amount $I_{t}$ in a project that produced a permanent return $\left(r_{t}\right)$, this project would have yielded the exact same present value as the one actually undertaken. The ratio, $q_{m t}=r_{t} / i_{t}$ is the key statistic in our analysis. If a company maximizes shareholder wealth, then it does not undertake an investment for which $q_{m t}<1$.

The market value of the company at the end of period $t\left(M_{t}\right)$ can be defined as follows:

$$
M_{t}=M_{t-1}+P V_{t}-\delta_{t} M_{t-1}+\mu_{t}
$$

In this equation, $P V_{t}$ is the present value of $I_{t}, \delta_{t}$ is the depreciation rate for the company's total capital as evaluated by the capital market, and $\mu_{t}$ is the market's error in evaluating $M_{t}$. Subtracting $M_{t-1}$ from both sides of (3) and replacing $P V_{t}$ with $q_{m t} I_{t}$ yields the following equation:

$$
M_{t}-M_{t-1}=q_{m t} I_{t}-\delta_{t} M_{t-1}+\mu_{t}
$$

Here $M_{t}-M_{t-1}$ is the change in the company's market value during the year $t$, and $q_{m t}$ is the ratio of return $\left(r_{t}\right)$ to $i_{t}$.

Equations (2) and (4) define the ratio of a company's return on investment to its cost of capital. It is evident that $q_{m t}$ is a marginal $q$ : consider Tobin's $q$ - the ratio of a company's market value and its total stock of capital, which is an average return on capital. Marginal $q$ is the change in the market value of the company divided by change in its capital stock (investment) that caused it.

It is convenient to illustrate these issues using two numerical examples:

In the first example, assume a given investment by a company of 100 produces a future stream of cash flows with a present value $\left(P V_{t}\right)$ of 132.62. If $\delta_{t}=\mu_{t}=0$ and the company invests at an $r_{t}>i_{t}$, then equation (4) implies that its market value increases by more than $100\left(I_{t}=100\right.$ and $P V_{t}=132.62, q_{m t}=1.3262$ ).

In another example, we assume $\mu_{t}=0$ and $r_{t}=i_{t}$. If $\delta_{t}=$ 0.05 and $M_{t-1}=1000$, then the company must invest 50 at an $r_{t}=i_{t}$ just to keep its market value unchanged.

Two additional features of marginal $q$ are worth noting. First, its use as a measure of performance obviates the need to calculate company costs of capital. Equations (2) and (4) define the ratio of a company's return on investment to its cost of capital, which is precisely the statistic needed to test our hypotheses. Second, the procedure for calculating $q_{m t}$ allows for different degrees of risks across companies. The stock market will demand a greater future stream of cash flows from an investment of 100 before it raises the market value of a high risk company by 100 , than it demands from a low risk company.

It is hypothesized that the change in market value is because of investment during $t\left(I_{t}\right)$, depreciation of assets $\left(\delta_{t}\right)$, and other factors that are reflected in the error term $\mu_{t}$. The assumption of capital market efficiency implies that the error term in equation (4) has an expected value of zero. Thus, (3) can be used to estimate both depreciation $\left(\delta_{t}\right)$ and marginal $q\left(q_{m}\right)$ under the assumption that they are either constant across companies or over time, or both. Dividing both sides of (4) by $M_{t-1}$ yields the following equation:

$$
\left(M_{t}-M_{t-1}\right) / M_{t-1}=-\delta+q_{m} I_{t} / M_{t-1}+\mu_{t} / M_{t-1}
$$

The equation's left hand side is the relative change in the market value of the company during the year $t$.

Equation (5) is favored over other possible rearrangements of (4) because, in cross-section regressions, it is less likely to be subject to heteroscedasticity owing to the deflation of all error terms by $M_{t-1}{ }^{6}$. The depreciation rate $(-\delta)$ represents

\footnotetext{
${ }^{6}$ Although both the market value of the company, $M$ and its investment, $I$ carry a $t$ subscript, equation (5) does not suffer from a simultaneous equation bias. $M_{t}$ is a company's market value at the end of year $t$, while $I_{t}$ is the investment flow over the year $t$. Thus, $I_{t}$ is measured before $M_{t}$ and can be treated as exogenous. A possible bias in estimating the returns on investment relative to the cost of capital using (5) arises, if the market anticipates the investments to be made in the future and the returns on them. Equation (5) accurately estimates marginal $q\left(q_{m}\right)$ even if the market correctly anticipates these investments at $t-1$, if the expected returns on future investments equal a company's cost of capital $(r=i)$. The methodology will yield lower (higher) estimates of $q_{m}$ and $\delta$ if at $t-1$ the market correctly anticipates investment at $t$ with returns $\mathrm{r}>\mathrm{i}(\mathrm{r}<\mathrm{i})$. Thus, when we conduct empirical analysis of agency problems with $\mathrm{r}<\mathrm{i}$, we are likely to under estimate agency problems. For a comprehensive discussion and evidence on no systematic bias in the estimates see Mueller and Yurtoglu (2000).
} 
the expected fall in a company's market value during any given year in which there was no investment. It is not only a measure of the decline in the value of a company's tangible assets, but also the decline in the value of its intangible assets (research and development and advertising expenditures) due to imitation by competitors and expiration of patents.

The annual change in the market value $\left(M_{t}-M_{t-1}\right)$ is partly due to random changes in the market sentiment that affect the market's valuation of its assets. In order to reduce the effects of changes in market sentiments, we transform $\left(M_{t}-M_{t-1}\right) / M_{t-1}$ and $I_{t} / M_{t-1}$ in each year as a deviation from the annual sample mean for estimating performance.

The estimation of equation (5) requires data on the market value of each company and its investments. The market value of a company at the end of $t, M_{t}$ is defined as the sum of the market value of its outstanding shares at the end of $t$ and the value of its outstanding debt ${ }^{7}$. Cash flow is defined as profit before taxes plus non-cash expenses-depreciation, amortization, royalty, plus cash generated from disposal of assets minus gain (loss) on disposal of assets minus taxes.

Investment is generated from cash flow, change in debt and equity offerings during the period $t$. Since research and development and advertising expenditures are also forms of investment that can produce "intangible capital" that contributes to a company's market value, they are added to total investment for measuring investment during $t$. Marginal $q$ 's on investment from cash flow, debt, and equity offerings are estimated by substituting investment in equation (5) by its components, cash flow $(C F)$, change in debt during the period $t(\triangle D)$, funds generated from equity offerings $(\Delta E)$ and estimating separate coefficients.

\section{Data}

A sample of 125 largest companies listed at the Karachi Stock Exchange was chosen that accounts for $98 \%$ of the stock exchange's capitalization. Financial companies are excluded from the sample because their capital is not comparable to non-financial companies.

Annual financial reports from 1997 to 2007 were solicited from the companies as well as from secondary sources of information such as the State Bank of Pakistan, and the Lahore Stock Exchange. Annual report discloses the cash received from public offerings of equity. The highest number of equity offerings of a company during 1997-2007 is 7. The stock prices data from 1996 to 2007 have been prepared from the newspapers, Dawn and Business Recorder. The ownership and financial information obtained from the above-mentioned sources was used to prepare panel data. The analysis uses unbalanced panels because all companies were not listed from 1997 to 2007. The Consumer Price Index (CPI) was used to convert nominal values of the financial variables into real 1991 Rupees.

\footnotetext{
${ }^{7}$ Market value is used for redeemable preference shares that are listed on the stock exchange. Book value is used for unlisted debt and financing facilities availed from financial institutions.
}

Redeemable preference shares are allowed by the Company's Share Capital Variation in Rights and Privileges Rules, 2000. Seven companies have issued redeemable preference shares that pay fixed annual dividends. In addition to redeemable preference shares, the firms analyzed in our sample, commonly use financing from financial institutions and debt issues to finance investment.

Summary statistics and matrix of correlation coefficients are reported in table II $(* * *, * *, *$ denote significance levels of $1 \%, 5 \%$, and $10 \%$ respectively). The Sidak method is used for assessing the significance levels of correlation coefficients (see Hamilton [17], pp 171-175).

\section{Empirical Analysis}

Panel regression estimations of marginal $q$ on investments from cash flow, debt, and equity offerings are reported in table III (In this and the following tables ***, **, * denote significance levels of $1 \%, 5 \%$, and $10 \%$ respectively).

The results reported in table III are robust ${ }^{8}$. The hypothesis that marginal $q\left(q_{m I}\right)$ equals 1 can be rejected. The return on investment relative to the cost of capital $\left(q_{m I}\right)$ is 0.69 . This suggests that dominant largest shareholders or managers invest beyond the optimal level of investment that maximizes the wealth of the shareholders, which leads to returns lower than the cost of capital. Thus, largest shareholders or managers pursue their own objectives.

Firm fixed effects and random effects are estimated and $q_{m \mathrm{I}}$ is unchanged. Pooled ordinary least squares are preferred over firm fixed effects because the null hypothesis of the Chow test for data pooling that deviations from the global intercept are zero for all companies cannot be rejected.

Investment $(I)$ in equation (5) is substituted by cash flow $(C F)$, change in debt $(\triangle D)$, and funds generated from equity offerings $(\triangle E)$ and marginal $q$ 's are estimated on $C F, \triangle D$ and $\triangle E$.

Depreciation is $13 \%$. The return on reinvested cash flow is $30 \%$ lower than the cost of capital. The hypothesis that $q_{m C F}$ equals 1 can be rejected at $1 \%$ significance level. There is strong evidence of the hypothesis that largest shareholders or managers of companies exercise discretion while reinvesting cash flows that leads to sub-optimal performance. Marginal $q$ on $\triangle D\left(q_{m D}\right)$ is less than 1 because the hypothesis that $q_{m D}$ equals 1 can be rejected at $1 \%$ significance level, which implies that investments with returns lower than the costs of capital are financed either from bank loans or by issuing debt.

Financial institutions in Pakistan are faced with asymmetric information during analysis of an investment's credit worthiness. Asymmetric information about the investment that is financed by the financial institution, among other factors, enables borrowers to obtain loans for investments that yield returns lower than the cost of capital.

\footnotetext{
${ }^{8}$ Quantile regression, robust regression, and regression with robust standard errors are used in STATA to check robustness.
} 
Table 2. Summary statistics of variables: means, medians and correlation coefficients

\begin{tabular}{|c|c|c|c|c|c|}
\hline $\begin{array}{l}\text { Summary } \\
\text { Statistics }\end{array}$ & $\left(M_{t}-M_{t-1}\right) / M_{t-1}$ & $I_{t} / M_{t-1}$ & $C F_{t} / M_{t-1}$ & $\Delta D_{t} / M_{t-1}$ & $\Delta E_{t} / M_{t-1}$ \\
\hline Mean & 0.22 & 0.23 & 0.12 & 0.04 & 0.03 \\
\hline (Median) & $(0.08)$ & $(0.14)$ & $(0.18)$ & $(0.26)$ & $(0.01)$ \\
\hline $\begin{array}{l}\text { Matrix of correlation } \\
\text { coefficients }\end{array}$ & $\left(M_{t}-M_{t-1}\right) / M_{t-1}$ & $I_{t} / M_{t-1}$ & $C F_{t} / M_{t-1}$ & $\Delta D_{t} / M_{t-1}$ & $\Delta E_{t} / M_{t-1}$ \\
\hline$I_{t} / M_{t-1}$ & $0.55^{* * *}$ & & & & \\
\hline$C F_{t} / M_{t-1}$ & $0.26^{* * *}$ & $0.54 * *$ & & & \\
\hline$\Delta D_{t} / M_{t-1}$ & $-0.19 * * *$ & $-0.65 * * *$ & -0.03 & & \\
\hline$\Delta E_{t} / M_{t-1}$ & -0.01 & -0.01 & 0.01 & -0.03 & \\
\hline
\end{tabular}

Table 3. Marginal $q$ on investment $(I)$, reinvested cash flow $(C F)$, and investment financed from debt $(\Delta D)$ and equity offerings $(\Delta E)$

Panel 1

\begin{tabular}{|c|c|c|c|c|c|c|}
\hline Full sample & $\begin{array}{c}-\delta \\
\text { Coeff. } \\
(\mathrm{SE})\end{array}$ & $\begin{array}{c}q_{m I} \\
\text { Coeff. } \\
\text { (SE) }\end{array}$ & $\left(q_{m} \neq 1\right)^{\mathrm{a}}$ & $b$ & $\begin{array}{c}\text { Adj. } \mathrm{R}^{2} \\
\text { /Within } \mathrm{R}^{2}\end{array}$ & Observations \\
\hline $\begin{array}{c}\text { Pooled ordinary } \\
\text { Least squares (OLS) }\end{array}$ & $\begin{array}{c}-0.17 \\
(0.012)\end{array}$ & $\begin{array}{l}0.69^{* * *} \\
(0.031)\end{array}$ & 0.000 & & 0.30 & 1203 \\
\hline Firm Fixed Effects & $\begin{array}{l}-0.18 \\
(0.012)\end{array}$ & $\begin{array}{l}0.74 * * * \\
(0.034)\end{array}$ & & 0.065 & 0.29 & 1203 \\
\hline Random Effects & $\begin{array}{c}-0.17 \\
(0.014)\end{array}$ & $\begin{array}{c}0.77 * * * \\
(0.033)\end{array}$ & & $\begin{array}{c}0.000 \\
\text { (assumed) }\end{array}$ & 0.29 & 1203 \\
\hline
\end{tabular}

\section{Panel 2}

\begin{tabular}{|c|c|c|c|c|c|c|c|}
\hline Full Sample & $-\delta$ & $q_{m C F}$ & $q_{m D}$ & $q_{m E}$ & $b$ & $\begin{array}{c}\text { Adj. } \mathrm{R}^{2} \\
\text { /Within } \mathrm{R}^{2}\end{array}$ & Observations \\
\hline $\begin{array}{l}\text { Pooled ordinary } \\
\text { Least squares }\end{array}$ & $\begin{array}{l}-0.13 \\
(0.012)\end{array}$ & $\begin{array}{l}0.70^{* * *} \\
(0.060)\end{array}$ & $\begin{array}{l}0.83^{* * *} \\
(0.039)\end{array}$ & $\begin{array}{c}0.01 \\
(0.013)\end{array}$ & & 0.33 & 1203 \\
\hline $\begin{array}{l}\text { Firm Fixed Effects } \\
\text { (FE) }\end{array}$ & $\begin{array}{l}-0.14 \\
(0.013)\end{array}$ & $\begin{array}{c}0.76^{* * *} \\
(0.072)\end{array}$ & $\begin{array}{l}0.84 * * * \\
(0.040)\end{array}$ & $\begin{array}{c}0.01 \\
(0.014)\end{array}$ & -0.065 & 0.33 & 1203 \\
\hline $\begin{array}{l}\text { Random Effects } \\
\text { (RE) }\end{array}$ & $\begin{array}{l}-0.13 \\
(0.014)\end{array}$ & $\begin{array}{l}0.72 * * * \\
(0.063)\end{array}$ & $\begin{array}{c}0.83 * * * \\
(0.039)\end{array}$ & $\begin{array}{c}0.01 \\
(0.013)\end{array}$ & $\begin{array}{c}0.000 \\
\text { (assumed) }\end{array}$ & 0.33 & 1203 \\
\hline \multirow{2}{*}{$\begin{array}{c}\text { Chow F-test } \\
\text { statistic for data } \\
\text { pooling }\end{array}$} & \multicolumn{5}{|c|}{$\mathrm{H}_{0}$ : Deviations from global intercept are zero for all companies } & \multicolumn{2}{|c|}{$\begin{array}{l}\text { F- statistic } \\
\text { (d.f.) }\end{array}$} \\
\hline & \multicolumn{5}{|c|}{ Pooled ordinary least squares (OLS) are preferred over firm fixed effects } & \multicolumn{2}{|c|}{$\begin{array}{c}1.16 \\
(121,1050)\end{array}$} \\
\hline \multirow{3}{*}{$\begin{array}{l}\text { Hausman } \\
\text { Test }\end{array}$} & \multirow{2}{*}{\multicolumn{5}{|c|}{$\begin{array}{l}\mathrm{H}_{0}: \text { Coefficients estimated by the efficient random effects estimator are asymptotically } \\
\text { identical to those estimated by the consistent fixed effects estimator }\end{array}$}} & \multicolumn{2}{|c|}{ Hausman test statistic ${ }^{\mathrm{c}}$} \\
\hline & & & & & & \multicolumn{2}{|c|}{1.37} \\
\hline & \multicolumn{5}{|c|}{ Random Effects (RE) are preferred over firm fixed effects (FE) } & & \\
\hline
\end{tabular}

${ }^{a}$-value of a Wald restriction test for " $q_{m}=1$ ”; ${ }^{b}$ correlation of effects and covariates, ${ }^{c}$ Null's distribution is Chi-square $\left(X^{2}\right)$ with three degrees of freedom.

Table 4. Marginal $q$ on investment $(I)$, reinvested cash flow $(C F)$, investment financed from debt $(\triangle D)$ and offerings of equity $(\Delta E)$ : Foreign-owned and Locally-owned companies

\section{Panel 3}

\begin{tabular}{|c|c|c|c|c|c|c|}
\hline $\begin{array}{l}\text { Foreign-owned } \\
\text { companies }\end{array}$ & $\begin{array}{c}-\delta \\
\text { Coeff. } \\
\text { (SE) }\end{array}$ & $\begin{array}{c}q_{m I} \\
\text { Coeff. } \\
\text { (SE) }\end{array}$ & $\left(q_{m} \neq 1\right)^{a}$ & $b$ & $\begin{array}{c}\operatorname{Adj}^{2} \\
\text { / Within } \mathrm{R}^{2}\end{array}$ & Observations \\
\hline $\begin{array}{l}\text { Pooled ordinary } \\
\text { Least squares }\end{array}$ & $\begin{array}{c}-0.17 \\
(0.023)\end{array}$ & $\begin{array}{c}0.87 * * * \\
(0.070)\end{array}$ & 0.000 & & 0.30 & 412 \\
\hline Firm Fixed Effects & $\begin{array}{c}-0.18 \\
(0.024)\end{array}$ & $\begin{array}{c}0.95 * * * \\
(0.078)\end{array}$ & & -0.065 & 0.29 & 412 \\
\hline Random Effects & $\begin{array}{c}-0.17 \\
(0.025)\end{array}$ & $\begin{array}{c}0.88 * * * \\
(0.071)\end{array}$ & & $\begin{array}{c}0.000 \\
\text { (assumed) }\end{array}$ & 0.29 & 412 \\
\hline \multirow{2}{*}{$\begin{array}{c}\text { Chow F-test } \\
\text { statistic for data pooling }\end{array}$} & \multicolumn{4}{|c|}{$\mathrm{H}_{0}$ : Deviations from global intercept are zero for all companies } & \multicolumn{2}{|c|}{$\begin{array}{c}\text { F-statistic } \\
\text { (d.f.) }\end{array}$} \\
\hline & & & & & \multicolumn{2}{|c|}{$\begin{array}{c}1.16 \\
(42, .358)\end{array}$} \\
\hline
\end{tabular}


Panel 4

\begin{tabular}{|c|c|c|c|c|c|c|c|}
\hline $\begin{array}{l}\text { Pooled ordinary } \\
\text { Least Squares }\end{array}$ & & $-\delta$ & $q_{m C F}$ & $q_{m D}$ & $q_{m E}$ & Adj.R2 & Observations \\
\hline $\begin{array}{c}\text { Foreign-owned } \\
\text { Companies }\end{array}$ & & $\begin{array}{l}-0.15 \\
(0.023)\end{array}$ & $\begin{array}{l}1.17 * * * \\
(0.142)\end{array}$ & $\begin{array}{c}0.99 * * * \\
(0.086)\end{array}$ & $\begin{array}{c}0.77 * * * \\
(0.278)\end{array}$ & 0.34 & 412 \\
\hline $\begin{array}{c}\text { Locally-owned } \\
\text { Companies }\end{array}$ & & $\begin{array}{c}-0.13 \\
(0.014) \\
\end{array}$ & $\begin{array}{c}0.59 * * * \\
(0.063) \\
\end{array}$ & $\begin{array}{l}0.77 * * * \\
(0.042) \\
\end{array}$ & $\begin{array}{c}0.01 \\
(0.012)\end{array}$ & 0.35 & 790 \\
\hline \multicolumn{8}{|l|}{ Panel 5} \\
\hline $\begin{array}{c}\text { Foreign-owned } \\
\text { companies }\end{array}$ & $-\delta$ & $q_{m C F}$ & $q_{m D}$ & $q_{m E}$ & $\mathrm{~b}$ & Within R2 & Observations \\
\hline Random Effects & $\begin{array}{c}-0.15 \\
(0.024)\end{array}$ & $\begin{array}{l}1.20^{* * *} \\
(0.146)\end{array}$ & $\begin{array}{c}0.99 * * * \\
(0.086)\end{array}$ & $\begin{array}{c}0.78 * * * \\
(0.278)\end{array}$ & $\begin{array}{c}0.000 \\
\text { (assumed) }\end{array}$ & 0.34 & 412 \\
\hline $\begin{array}{l}\text { Hausman } \\
\text { Test }\end{array}$ & \multicolumn{5}{|c|}{$\begin{array}{l}\mathrm{H}_{0} \text { : Coefficients estimated by the efficient random effects estimator are asymptotically } \\
\text { identical to those estimated by the consistent fixed effects estimator }\end{array}$} & Hausm & $\begin{array}{l}\text { Test Statisticc } \\
1.37\end{array}$ \\
\hline
\end{tabular}

${ }^{a} \mathrm{p}$-value of a Wald restriction test for " $q_{m}=1$ "; ${ }^{b}$ correlation of effects and covariates. ${ }^{c}$ Null's distribution is Chi-square $\left(X^{2}\right)$ with three degrees of freedom.

Delinquent borrowers sometimes confront financial institutions seeking to recover past due loans. Delinquencies of loans are frequent and financial institutions are often unable to sell collateralized assets for recovering outstanding loans. Debt is frequently used for financing investments as loans from financial institutions and issuance of bonds and other debt instruments do not dilute the concentrated shareholdings of largest shareholders. Thus, largest shareholders or managers prefer financing from financial institutions over equity as foreclosure laws are weak and the transaction costs of issuing equity are high.

The null hypothesis of the Chow test for data pooling that deviations from the global intercept are zero for all companies cannot be rejected. Pooled ordinary least squares are preferred over firm fixed effects (FE). The marginal $q$ estimates obtained from the random effects (RE) model are unchanged. The null hypothesis of the Hausman test cannot be rejected. Thus, the test result supports the random effects estimation over the firm fixed effects estimation.

Marginal $q$ estimates for foreign-owned companies are reported in Table $4(* * *, * *$, * denote significance levels of $1 \%, 5 \%$, and $10 \%$ respectively). The results are robust. Depreciation is $17 \%$. The hypothesis that marginal $q$ on investment $\left(q_{m I}\right)$ equals 1 can be rejected, which implies that return on investment is lower than the cost of capital.

Return on investment from debt equals the cost of capital because the hypothesis that $q_{m D}$ equals 1 cannot be rejected. There is strong evidence of market discipline on investment financed from debt. Return on investment from equity offerings is $23 \%$ less than the cost of capital. The hypothesis that marginal $q$ on investment financed from equity offerings $\left(q_{m E}\right)$ equals 1 can be rejected at $1 \%$ significance level. This implies that managers of foreign-owned companies issue equity to finance investments that yield returns lower than the costs of capital.

Pooled ordinary least squares (OLS) are preferred over firm fixed effects as the null hypothesis of the Chow test for data pooling cannot be rejected. Random effects are preferred over firm fixed effects because the null hypothesis of the Hausman test cannot be rejected (results of firm fixed effects are not reported to save space).
Marginal $q$ for locally-owned companies is reported in Table $4(* * *, * *, *$ denote significance levels of $1 \%, 5 \%$, and $10 \%$ respectively). The results are robust. Depreciation is $17 \%$. The hypothesis that $q_{m C F}$ equals 1 can be rejected. Return on reinvested cash flow is $41 \%$ lower than the cost of capital. This implies that largest shareholders or managers exercise discretion while reinvesting cash flows.

The return on investment financed from debt is significantly lower than the cost of capital because the hypothesis that $q_{m D}$ equals 1 can be rejected at $1 \%$ significance level. There is evidence that investments yielding returns lower than the cost of capital are financed either by issuing debt or from loans of financial institutions. Asymmetric information, among other factors, enables borrowers to avail financing for investments that yield returns lower than the costs of capital.

\section{Concluding Section}

This is the first essay on Pakistan that uses panel data modeling for estimating marginal $q$ on reinvested cash flow, investments financed from debt and equity.

There is strong evidence of our hypothesis that the return on investment relative to the cost of capital is less than 1 for Pakistan. Return on investment is unambiguously lower than the cost of capital. This evidence is confirmed by firm fixed effects (FE) and random effects (RE). Dominant largest shareholders or managers exercise discretion while investing. Instead of maximizing the wealth of shareholders, they invest beyond the optimal level of investment. They pursue their own objectives.

Currently, Pakistan's corporate governance system is weak and is unable to properly protect outside shareholders from expropriation of largest shareholders or managers, which among other factors could lead to outflow of portfolio investments from the equity market (see Johnson et al. [18]).

Return on reinvested cash flow is $30 \%$ lower than the cost of capital. There is evidence of our hypothesis that largest shareholders or managers exercise discretion while reinvesting cash flows, which among other factors, leads to 
sub-optimal performance. They reinvest cash flows in investments that yield returns lower than the costs of capital. The return on reinvested cash flow is lower than the cost of capital especially, for locally-owned companies confirming the evidence that discretion is used while reinvesting cash flows.

The return on investment from debt is $17 \%$ less than the cost of capital. This implies that investments with returns lower than the costs of capital are financed either from issuing debt or borrowings from financial institutions that are faced with asymmetric information while appraising the credit worthiness of an investment. Financial institutions are sometimes unable to dispose collateralized assets for recovering delinquent loans as foreclosure laws are weak in Pakistan. The weak corporate governance system is unable to protect financial institutions from loan delinquencies.

Return on investment from debt is significantly lower than the cost of capital, which implies that companies finance sub-optimal investments either from debt issues or from loans of financial institutions that are sometimes unable to sell collateralized assets for recovering delinquent loans because foreclosure laws are weak. Since the transaction costs of public offerings of equity are high and the foreclosure laws are weak, largest shareholders or managers seem to prefer debt over equity.

The results of the panel-data regressions provide evidence that return on investment of foreign-owned companies is unambiguously lower than the cost of capital. Foreign-owned companies exhibit evidence of market discipline as the return on investment financed from debt equals the cost of capital.

Return on investment from equity is $23 \%$ lower than the cost of capital. This implies that foreign-owned companies use equity offerings for investments that yield returns lower than the costs of capital. Corporate governance institutions are weak in Pakistan and they are unable to control managers from issuing equity for investments that yield returns lower than the costs of capital.

\section{Acknowledgements}

We are grateful to the Austrian Agency for International Cooperation in Education and Research and the Higher Education Commission that supported the research. We are grateful to Tanvir Afgan, Abdul Aziz Anis, Muhammad Afzal, Hasan Ashraf, Ashraf Bawa, M. Salman Ali Bokhari, Bilal Durrani, Tanveer Iqbal, Florian Gach, Klaus Gugler, Assad Hameed Khan, Robert M. Kunst, S. M. Saad Jafri, Saqib Masood, Arshad Mahmood, Nasrullah Mand, Farhan Talib, Bilal Rasul, Heide Marie Wurm, and Besim Burcin Yurtoglu for their cooperation in the process of collecting information.

\section{Appendix}

\section{Definitions}

One share- one vote principle: Each common share carries one vote.

Dispersed Shareholdings: Percentage of shares owned by a large number of individual shareholders in a publiclylisted company.

Institutional Ownership (IT): Percentage of shares owned by outside institutional shareholders in a listed company.

Outside Shareholders comprise of non-financial companies, non-governmental organizations (NGOs), trusts, charitable institutions, and association of persons.

None of the ownership structures analyzed in this essay have dispersed shareholders as the largest direct shareholders.

Zimpex Private Limited is the largest direct shareholder of Kohinoor Textile Mills. Zimpex Private is incorporated in Lahore (refer to Figure 1). The authorized capital of Zimpex Private Limited is 5 million Rupees and paid-up capital is 1 million Rupees.

\section{REFERENCES}

[1] J. Tobin. A General Equilibrium Approach to Monetary Theory. Journal of Money Credit and Banking, Vol. 1, No.1, 15-29, 1969.

[2] F. Hayashi. Tobin's marginal $q$ and average $q$ : a neo-classical interpretation. Econometrica, Vol. 50, No.1, 213-224, 1982.

[3] T. Hoshi, A. Kashyap, D. Scharfstein. Corporate Structure Liquidity, and Investment: Evidence from Japanese Industrial Groups. Quarterly Journal of Economics, Vol.106, No.1, 33-60, 1991.

[4] S. M. Fazzari, G.R. Hubbard. Financing Constraints and Corporate Investment. Brookings Paper on Economic Activity, 141-195, 1988.

[5] S.C. Myers. The Capital Structure Puzzle. The Journal of Finance. Vol. 39, No.3, 575-592, 1984.

[6] S.C. Myers. Financing of Corporations. Handbook of the Economics of Finance.

[7] A. Singh. How do Large Corporations in Developing Countries Finance Growth. American Express Bank Prize Essays: 120-142, 1994.

[8] A. Singh. Corporate Financial Patterns in Industrialising Economies: A Comparative International Study. IFC Technical Paper No. 2, World Bank, Washington, DC, 1-34, 1995

[9] D.C. Mueller, B.B. Yurtoglu. Country Legal Environments and Corporate Investment Performance. German Economic Review, Vol. 1, No.1, 187-220, 2000.

[10] K. Gugler, D.C. Mueller, B.B. Yurtoglu. Corporate Governance and Returns on Investment, Journal of Law and Economics, Vol. 47, No.1, 589-633, 2004. 
[11] F.A. Samad. Ownership Structure in the Malaysian Corporate Sector: Its Impact on Corporate Governance, Performance, Financing, and Investment Patterns. Working Paper; University of Manchester, 2002.

[12] D.C. Mueller. The Anglo-Saxon approach to Corporate Governance and its Applicability to Emerging Markets. Corporate Governance: An International Review, Vol. 14, No.4, 207-219, 2006.

[13] E.B. Patty, D.C. Hardy. Financial Sector Liberalization, Bank Privatization, and Efficiency: Evidence from Pakistan. Journal of Banking and Finance, Vol. 29, No.8-9, 2381-2406, 2005.
[14] R. Adams, D. Ferreira. One-Share- One Vote: The Empirical Evidence, Review of Finance, Vol. 12, No.1, 51-91, 2008.

[15] H.V. Almeida, D. Wolfenzon. A Theory of Pyramidal Ownership and Family Business Groups, Journal of Finance, Vol. 61, No.6, 2637-2680, 2006.

[16] D.C. Mueller, E. Reardon. Rates of Return on Corporate Investment. Southern Economic Journal, Vol. 60, No.1, 430-453, 1993.

[17] L.C. Hamilton. Statistics with Statistics, Duxbury, Canada, 1992.

[18] S. Johnson, P. Boone, A. Breach, E. Freidman. Corporate Governance in the Asian Financial Crisis. Journal of Financial Economics, Vol. 58, No. 1-2, 141-186, 2000. 